\title{
Development and validation of analytical method by HPLC-DAD for determination of vasodilator active in pharmaceutical ophthalmic forms
}

\author{
Aina Liz Alves Cesar¹, Larissa Caldeira Navarro, Alaíde de Matos Silva1, Rachel Oliveira Castilho, \\ Gisele Assis Castro Goulart ${ }^{1}$, Giselle Foureaux Heida², Anderson José Ferreira ${ }^{2}$, Sebastião \\ Cronemberger ${ }^{3}$, André Augusto Gomes Faraco ${ }^{1 *}$ \\ ${ }^{1}$ Faculdade de Farmácia, Universidade Federal de Minas Gerais (UFMG), Belo Horizonte, MG, Brasil \\ ${ }^{2}$ Departamento de morfologia, Instituto de Ciências Biológicas, Universidade Federal de Minas Gerais (UFMG), Belo Horizonte, \\ MG, Brasil \\ ${ }^{3}$ Faculdade de Medicina, Universidade Federal de Minas Gerais (UFMG), Belo Horizonte, MG, Brasil \\ *Corresponding author: andrefaraco@ufmg.br
}

\begin{abstract}
The substance 4-Aminobenzamidine dihydrochloride (4-AD) is one of the degradation products of diminazene aceturate and has demonstrated antiglaucomatous potential. Glaucoma is the second leading cause of blindness worldwide; thus, new therapeutic alternatives must be studied, for example, the molecule 4-AD vehiculated into polymeric inserts for prolonged release. The present work aims to develop and validate an analytical method to quantify 4-AD in pharmaceutical ophthalmic forms. A HPLC was used with UV-Vis detector, at $290 \mathrm{~nm}$ and ACE $^{\circledR}$ C18 column $(125 \times 4.6 \mathrm{~mm}, 5 \mu \mathrm{m})$, in which the mobile phase consists of phosphate buffer $(\mathrm{pH} 7.4)$ and triethylamine $(30 \mathrm{mmol} / \mathrm{L})$, under an isocratic flow of $1.0 \mathrm{~mL} / \mathrm{min}$. The retention time of 3.2 minutes was observed. The method was developed and validated in accordance with ANVISA recommendations and $\mathrm{ICH}$ guides. The linearity range was established between the concentrations 5 and $25 \mu \mathrm{g} / \mathrm{mL}$ (correlation coefficient $r=0.993$ ). The accuracy, repeatability, and intermediate precision tests obtained a relative standard deviation less than or equal to $5 \%$. In addition, the method was considered selective, exact. and robust, with $\mathrm{pH}$ being its critical factor. Therefore, the HPLC analysis method is robust and can be used to quantify 4-AD in pharmaceutical forms for ocular application.
\end{abstract}

Keywords: HPLC. Method Validation. Ophthalmic Insert. 4-AD. Diminazene Aceturate.

\section{How to cite}

Cesar ALA, Navarro LC, Silva AM, Castilho RO, Goulart GAC, Heida GF, Ferreira AJ, Cronemberger S, Faraco AAG. Development and validation of analytical method by HPLC-DAD for determination of vasodilator active in pharmaceutical ophthalmic forms. Rev Ciênc Farm Básica Apl. 2020;41:e636. https://doi.org/10.4322/2179-443X.0636

\section{INTRODUCTION}

Primary open-angle glaucoma (POAG), characterized by increased intraocular pressure (IOP) in the anterior chamber and a damage to the optic nerve, is classified as the second leading cause of blindness worldwide (Benoist d'Azy et al., 2016). Its therapy requires multiple

Financial support: This work was supported by PRPq-UFMG, CNPq (for Development Technologic fellowship - 310347/2014-9), and FAPEMIG (Brazil). The author would like to thank CAPES for the scholarship (CAPES-Brasília/Brazil).

Conflicts of interest: The authors have no conflict of interest to declare.

Received on March 18, 2020. Accepted on June 08, 2020. 
daily instillations to obtain a suitable therapeutic response, but this may compromise patient's compliance. In addition, more than $90 \%$ of the administered dose is drained by the nasolacrimal duct, reaching the systemic circulation, which leads to adverse effects (Karki et al., 2016; Mu et al., 2018; Sharif, 2017; Zhu et al., 2018).

To overcome these problems many formulations have been developed, such as contact lenses (Carvalho et al., 2015; Desai et al., 2018, Alvarez-Lorenzo et al., 2019), nanosuspensions, nanoparticles (Gupta et al., 2010; Mu et al., 2018), polymeric nanocarriers (cyclodextrins, dendrimers) (Calles et al., 2015; Carta et al., 2015; Rodriguez-Aller et al., 2015), and lipid nanoparticles (Gooch et al., 2012; Wang et al., 2015, 2017). Ophthalmic inserts are another formulation that can be used. This prolonged release system reduces systemic side effects and the frequency of administration, leading to better treatment outcomes (Karki et al., 2016; Wang et al., 2018; Yadav et al., 2019). The inserts are less associated with eye irritation and they do not leave sticky sensation on the application side, which is an advantage over other forms of drug release (Franca et al., 2014; Souza et al., 2016; Karki et al., 2016).

Diminazene aceturate (DIZE) can be degraded into two molecules; 4-aminobenzamidine and 4-amidinophenyldiazonium salt (Campbell et al., 2004). The use of 4-Aminobenzamidine Dihydrochlorid (4-AD, Figure 1) consists on an innovation over the therapies currently available to treat glaucoma, studies have shown that this compound could reduce intraocular pressure and protect the retinal ganglion cells from degeneration caused by the pathological process of glaucoma (Foureaux et al., 2015; Faraco et al., 2020).

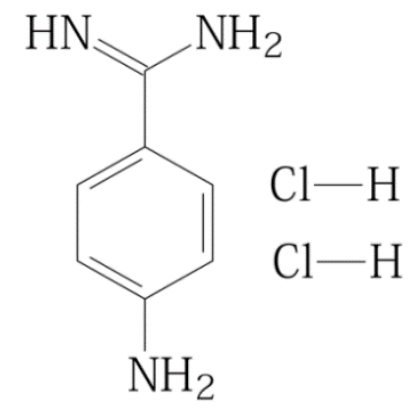

Figure 1. Chemical representation for the structure of 4-AD

As 4-AD is not considered a drug yet, no official assay method is available in compendia (pharmacopoeias). Atsriku et al. (2002) and Campbell et al. (2004) described the determination and identification of DIZE and its degradation products by liquid chromatography coupled with mass spectrometry (LC-MS). However, these methods are not suitable for 4-AD quantification, require complex instrumentation, and are more expensive than high performance liquid chromatography (HPLC) (Maia et al., 2015). Hence, the development of an analytical method is necessary to detect and identify 4-AD in pharmaceutical forms. Therefore, we developed and validated a quantitative method employing high performance liquid chromatography.

\section{MATERIAL AND METHODS}

All reagents used were of analytical grade and the solutions were prepared in Milli-Q purified water (Millipore, Billerica, USA). The 4-Aminobenzamidine Dihydrochloride was purchased from Sigma-Aldrich (Sigma-Aldrich, Germany), batch \#MKBV0640V, content of 98\%. Chondroitin sulphate (chondroitin 4-sulfate sodium salt, $45000 \mathrm{Da}$ ) was purchased from Galena Chemical and Pharmaceutical Ltda. (Campinas, Brazil). Medium molecular weight chitosan (200000 Da) and the dye Lissamine ${ }^{\mathrm{TM}}$ Green B was purchased from Sigma-Aldrich (St. Louis, Mo, USA). 


\subsection{Insert preparation}

Chitosan (Chs) and chondroitin (CS) inserts, stained with Lissamine ${ }^{\mathrm{TM}} \mathrm{Green} \mathrm{B}$, and carrying the active 4-AD were produced by the solvent casting technique (Rodrigues et al., 2009). First, $180 \mathrm{~g}$ of $4-\mathrm{AD}$ and $25 \mu \mathrm{L}$ of dye solution were added in $1 \% \mathrm{w} / \mathrm{v}$ acetic acid, and then $1 \mathrm{~g}$ of each polymer was solubilized and homogenized. The final gel was magnetically stirred overnight, poured into circular silicone-molded trays containing individual wells $(5 \times 2 \mathrm{~mm})$, and left at room temperature for drying. The final inserts were calibrated using a $5 \mathrm{~mm}$ punch.

\subsection{HPLC parameters and validation method}

Validation of the analytical method was performed in accordance with RDC $n^{\circ} 166 / 2017$, Brazilian pharmacopoeia and ICH guides (International Conference on Harmonisation of Technical Requirements for Registration of Pharmaceuticals for Human Use, 2005; Brasil, 2017; Agência Nacional de Vigilância Sanitária, 2019; Maia et al., 2015). The chromatographic analysis was performed on Chromatograph Agilent Technologies 1260, coupled to EzChrom program (Agilent Technologies, CA, USA) with a ACE $^{\circledR}$ C18 column $(125 \times 4.6 \mathrm{~mm}, 5 \mu \mathrm{m})$ at $30^{\circ} \mathrm{C}$. The mobile phase was phosphate buffer $(\mathrm{pH} \mathrm{7.4)}$ with TEA $30 \mathrm{mmol} / \mathrm{L}$ at the ideal flow $(1.0 \mathrm{~mL} / \mathrm{min})$. For this purpose, the system was adapted based on the parameters defined in the literature: number of theoretical plates $>3000$, asymmetry $<1.5$, and relative standard deviation $<2 \%$ (Snyder et al., 1997; International Conference on Harmonisation of Technical Requirements for Registration of Pharmaceuticals for Human Use, 2005; Agência Nacional de Vigilância Sanitária, 2019; Maia et al., 2015).

To validate the analytical method, placebo inserts were contaminated with a known concentration of 4-AD; then, they were dried again and finally solubilized in acetic acid $1 \%(\mathrm{v} / \mathrm{v})$. The final solution was filtered through $0.45 \mu \mathrm{m}$ and dilutions were performed to obtain the desired concentrations.

The validation followed in accordance with the resolution of the collegial board of directors RDC $n^{\circ} 166 / 2017$ and the ICH guide for validation. The selectivity was evaluated by overlapping the matrix components and by evaluation of the peak purity of the active 4-AD (International Conference on Harmonisation of Technical Requirements for Registration of Pharmaceuticals for Human Use, 2005; Agência Nacional de Vigilância Sanitária, 2019).

The linearity was demonstrated by reading five different concentration levels $(5,10,15,20$, and $25 \mu \mathrm{g} / \mathrm{ml})$. The solutions were prepared in triplicate and the graph "Concentration $\times$ Area" was plotted. According to the current legislation, the acceptance criteria involves the correlation coefficient ( $r$ ) greater than 0.990 and the angular significantly different from zero $(p<0.05)$. The statistical analysis was performed in the GraphPad Prism 5.0 program (GraphPad Software, San Diego) (Brasil, 2017).

The detection limit (DL) shows the smallest detectable amount (but not necessarily quantifiable) of the analyte in a sample and the limit of quantification (LQ) is the smallest amount of analyte that can be determined with precision and accuracy. Both limits were calculated with the formulas: $\mathrm{DL}=3.3 \times \sigma / \mathrm{IC}$ and $\mathrm{LQ}=10 \times \sigma / \mathrm{IC}$, respectively. Where $\sigma$ is the standard deviation of the intercept with the $y$-axis, and IC is the slope of the calibration curve (Agência Nacional de Vigilância Sanitária, 2019).

The precision must be demonstrated by calculating the relative standard deviation (RSD) of nine measurement series (low, medium, and high concentrations, contemplating the linear range) according to the formula $\mathrm{RSD}=(\mathrm{SD} / \mathrm{MCD}) \times 100$, where $S D$ is the standard deviation and MCD is the mean concentration determined (International Conference on Harmonisation of Technical Requirements for Registration of Pharmaceuticals for Human Use, 2005).

Repeatability analysis was evaluated using the means of nine triplicates in concentrations 5,15 , and $25 \mu \mathrm{g} / \mathrm{mL}$, which refers to the agreement between the results in a short period of time with the same analyst and instrumentation. The intermediate precision was also analyzed by a triplicate of points on different days with solutions prepared by different analysts; the result must not exceed 5\% RSD (International Conference on Harmonisation of Technical Requirements for Registration of Pharmaceuticals for Human Use, 2005). 
The accuracy was determined by the degree of agreement between the quantification results of the method in relation to the known concentration of 4-AD in the presence of the components of the formulation, nine measurement series $(5,15$, and $25 \mu \mathrm{g} / \mathrm{mL}$ concentrations in triplicate). For this, nine inserts consisting of chondroitin sulfate and chitosan (Chs:SC) were fortified with 4-AD solution of the active, and the results were expressed as the percentage of the active recover (International Conference on Harmonisation of Technical Requirements for Registration of Pharmaceuticals for Human Use, 2005; França et al., 2015; Agência Nacional de Vigilância Sanitária, 2019).

Changes in the chromatographic parameters were evaluated as recommended in RDC $n^{\circ} 166 / 2017$ for robustness. Some conditions of the analytical method were modified such as conditions of flow $( \pm 0.1 \mathrm{~mL} / \mathrm{min})$, temperature $\left( \pm 3^{\circ} \mathrm{C}\right)$, and the TEA concentration in the mobile phase $( \pm 3 \mathrm{mmol} / \mathrm{L})$. Nine determinations were performed in three concentrations (low, medium, and high). The results obtained with the modified parameter were compared with the expected result under the standard chromatographic conditions (Maia et al., 2015; Agência Nacional de Vigilância Sanitária, 2019).

\subsection{Statistical analysis}

The software GraphPad Prism 5.0 (GraphPad Software Inc., USA) was used. The analysis of variance (ANOVA, $p<0.05$ ) was performed and the relative standard deviation (RSD) was defined as acceptable when $<5 \%$.

\section{RESULTS}

The best method consists in an $A C E^{\circledR} \mathrm{C} 18(125 \times 4.6 \mathrm{~mm}, 5 \mu \mathrm{m})$ column with isocratic elution at $1.0 \mathrm{~mL} / \mathrm{min}\left(30^{\circ} \mathrm{C}\right)$ and phosphate buffer (TEA $30 \mathrm{mmol} / \mathrm{L} ; \mathrm{pH} 7.4$ ) as mobile phase. The volume of injection was $20 \mu \mathrm{L}$, and the detection was performed at $290 \mathrm{~nm}$ (Figure 2). The chromatographic parameters (asymmetry and peak purity) were adjusted according to the system suitability specifications: the tailing factor for the active was $1.2(<1.5)$. The other parameters evaluated were the number of plates 5034 (>3000) and RSD between replicates (<2\%) (Snyder et al., 1997; Agência Nacional de Vigilância Sanitária, 2019). These data demonstrate that the peak obtained for substance 4-AD can be used in its quantification. The method proved to be selective to quantify the active 4-AD. When an insert sample was analyzed, the components of the matrix (chitosan, chondroitin, and the dye) did not interfere in the retention time, which remained similar to the active (Figure 3).

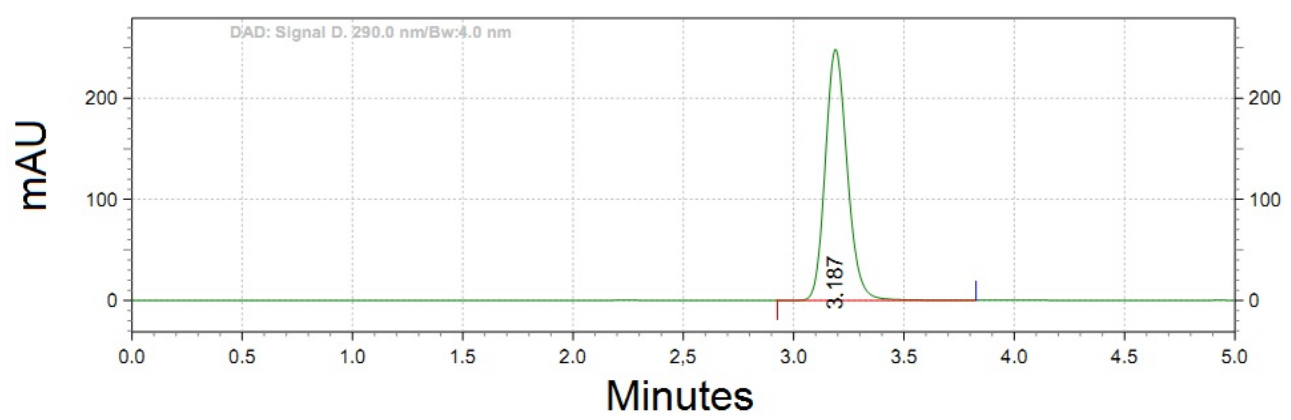

Figure 2. Chromatogram obtained for active substance 4-AD through the developed method 


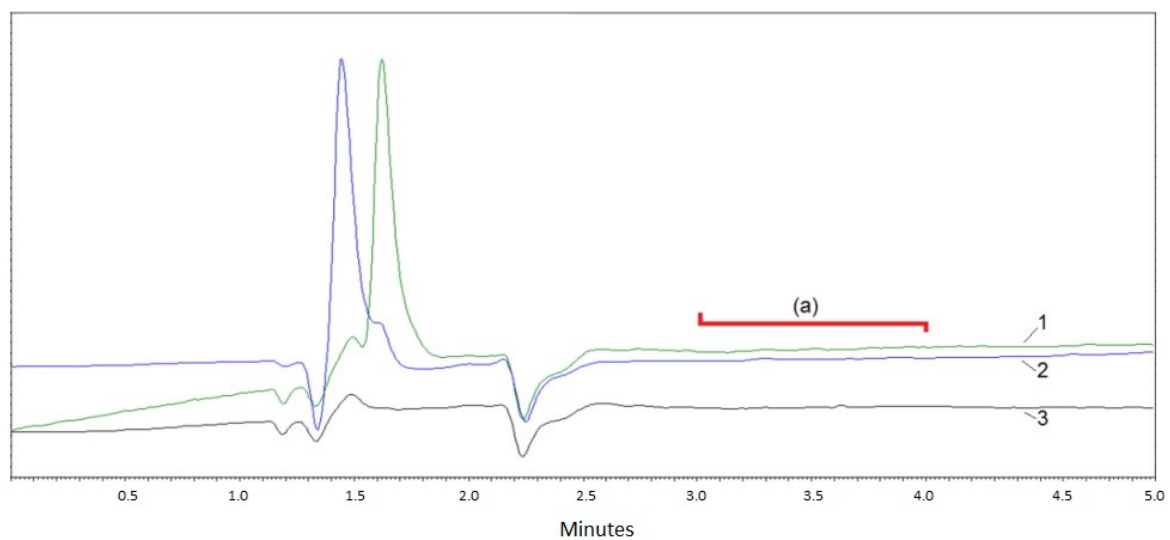

Figure 3. Chromatograms indicating that CS (1), ChS (2); Lissamine (3) do not come out in the same retention time as the active $4-A D(a)$.

Moreover, it was linear in the range of 5 to $25 \mu \mathrm{g} / \mathrm{mL}$. The suitability of the model was confirmed by Analysis of Variance (ANOVA), performed in GraphPad Prism 5.0 software. The linear trend was significant with $p<0.05$, with a significant overlap between the three calibration curves $(p<0.05)$. The residue analysis was performed according to Ribeiro et al. (2008). As presented in Figure 4, the data has normal distribution with homoscedasticity. The equation of the calibration curve was $y=11800000 x-819900$; thus, the method was considered linear (Agência Nacional de Vigilância Sanitária, 2019).

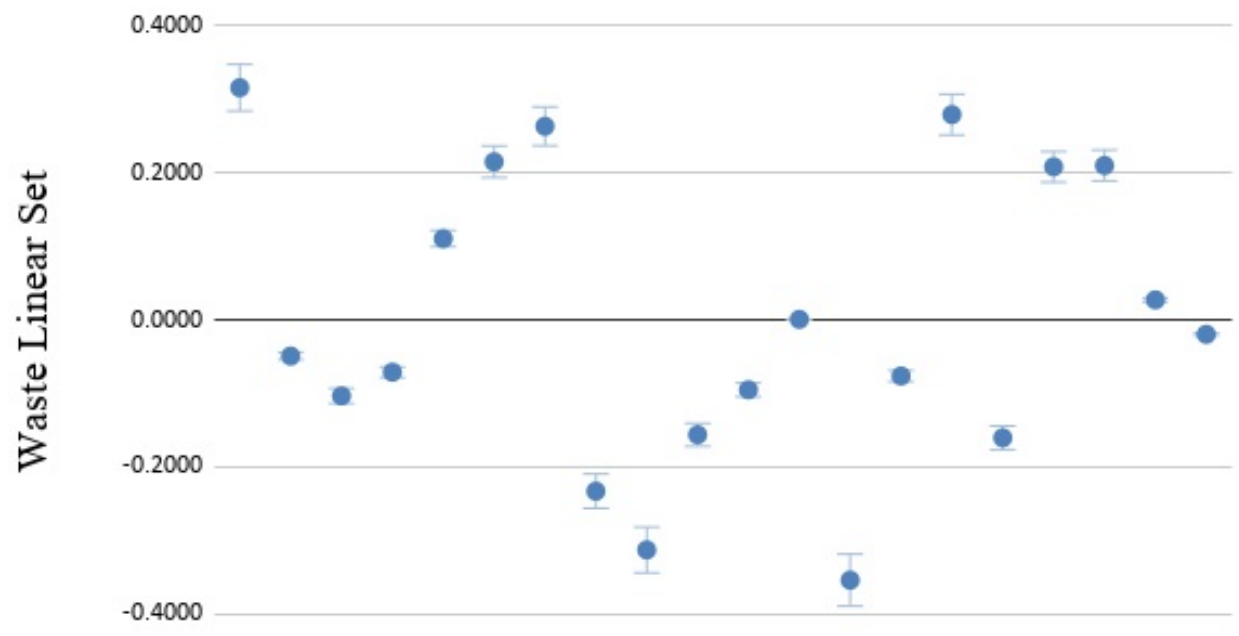

\section{Concentration $(\mu \mathrm{g} / \mathrm{mL})$}

Figure 4. Residue analysis demonstrating the normal distribution with homoscedasticity.

Based on the equation described, it was verified that the detection limit is $0.2337 \mu \mathrm{g} / \mathrm{mL}$ and the limit of quantification is $0.7791 \mu \mathrm{g} / \mathrm{mL}$. Intra-day and inter-day precision values are shown in Table 1, all are close to $100 \%$, that is, and it was possible to verify that there was no variation in the data obtained between the repetitions. It was calculated by means of the ratio between the experimental average concentration and the theoretical concentration (França et al., 2015). 
Table 1: Values for Intra-day and inter-day precision for the developed method.

\begin{tabular}{|c|c|c|c|c|c|c|}
\hline \multirow{2}{*}{$\begin{array}{c}C_{t} \\
\left(\mu g \mathrm{~mL}^{-1}\right)\end{array}$} & \multicolumn{2}{|c|}{ Repeatability } & \multicolumn{2}{|c|}{ Intermediate precision } & \multicolumn{2}{|c|}{ Accuracy } \\
\hline & MMC (n=3) & DPR & MMC $(n=6)$ & DPR & $\begin{array}{c}\text { Recovery } \\
\text { (\%) }\end{array}$ & DPR \\
\hline 5.00 & 4.90 & $0.03 \%$ & 4.97 & $0.03 \%$ & $98 \%$ & $3 \%$ \\
\hline 15.00 & 14.67 & $0.07 \%$ & 14.79 & $0.02 \%$ & $99 \%$ & $2 \%$ \\
\hline 25.00 & 25.14 & $0.01 \%$ & 24.90 & $0.01 \%$ & $101 \%$ & $1 \%$ \\
\hline
\end{tabular}

$\mathrm{Ct}=$ theoretical concentration, $\mathrm{MMC}=$ Mean measured concentration and $\mathrm{RSD}=$ relative standard deviation

As shown in Table 1, this method present adequate Repeatability and Intermediate precision for 4-AD assay of a series of measurements ( $R D S<5 \%$ ), which is in accordance with current legislation (Agência Nacional de Vigilância Sanitária, 2019). The accuracy is also in accordance with current legislation, the percentage of recovery is within the established range of 98 to $102 \%$, that is, the method can correctly dose $4-A D$ in ophthalmic insert with $99 \%$ accuracy ( $2 \%$ RSD). The robustness measured the sensitivity of the method in small variations $( \pm 10 \%)$ for the parameters of TEA concentration, flow, and temperature. The method presented adequate robustness since the analysis in triplicate of three concentration levels did not present RSD greater than $5 \%$. The robustness was evaluated by comparing the values obtained from the concentrations in the modified conditions in relation to the concentrations in normal condition. The analysis of the variables was assessed by the ANOVA with Dunnet post-test (95\% of confidence interval). The data treated using GraphPad Prism 5.0 Software demonstrated no statistical differences and the $F$ value from ANOVA was equal 1.164, between the values $(p<0.05)$ indicating that the method developed is robust. Using the proposed method, the assay was performed. The test was conducted in triplicate with a pool of 10 inserts solubilized in acetic acid. The amount of $30 \mu \mathrm{g}$ of 4-AD per insert was obtained (0.016\%).

\section{DISCUSSION}

There was no known method on the literature which specifically describes the identification and quantification of 4-Aminobenzamidine Dihydrochloride in ocular inserts. But this substance appears in the method described by Atsriku et al. (2002) to detect diminazene aceturate, as the 4-AD was one of its degradation products, this method, however, needs to be adapted since the retention time of the molecule of interest was very small, which makes its quantification imprecise. In addition, it involves HPLC-coupled mass spectrometry and this equipment makes the analysis more expensive (Snyder et al., 1997; Atsriku et al., 2002; Campbell et al., 2004; Foureaux et al., 2015). High-performance liquid chromatography is a simpler and low-cost method, which brings advantages with regard to its use. Therefore, this was the method of choice for this work (Maia et al., 2015; França et al., 2015).

The parameters used by Atsriku et al. (2002) were the starting point for the development of this method. The retention factor was the first variable analyzed it should be the closest to one and it should take in consideration the total running time and the dead time. To adjust this factor the composition of the mobile phase (buffer), the $\mathrm{pH}$ proved to be critical. Also at this stage we chose to add the triethylamine (TEA) in order to achieve suitable peak symmetry, as it prevents that amino 4-AD groups interacts with the column (Snyder et al., 1997; Maia et al., 2015).

It was chosen as mobile phase a buffer with $\mathrm{pH} 7.4$, as in this value the compound was predominantly in its ionized form. The protonated form interact strongly with silanol groups of the column, which would lead to an increase of the retention of the particles in the column causing a tail at the peak, which increases the parameter denominated tail factor (Snyder et al., 1997).

The selectivity was the following parameter to be analyzed, and it was kept under constant supervision should there be any change (Silva et al., 2014). The chromatograms resulting from 
these analyses can be observed in Figure 3, through this analysis it was possible observe that the matrix components did not leave at the 4-AD retention time (Figure 3-a). The chondroitin sulphate (CS) solution shows a small signal in 1.4 minutes and the chitosan (ChS) solution in 1.6. Both of them are far from the retention time of 4-AD, which is 3.2 minutes; there was also no absorption at the wavelength of $290 \mathrm{~nm}$ chosen for the determination of the active.

The correlation coefficient was equal to 0.993 that is, the obtained points were little dispersed and were ideal for use in the calibration curve. This value is in accordance with the one recommended by ANVISA and the $\mathrm{ICH}$ guide for validation of analytical methods (International Conference on Harmonisation of Technical Requirements for Registration of Pharmaceuticals for Human Use, 2005; Agência Nacional de Vigilância Sanitária, 2019). The recovery percentage was close to $100 \%$, proving everything that was previously said and demonstrating that the method can be considered exact (França et al., 2015; Agência Nacional de Vigilância Sanitária, 2019).

Robustness was evaluated by varying the following chromatographic conditions by $\pm 10 \%$ : flow, temperature, and TEA concentration. The $\mathrm{pH}$ was not varied, because during the development of the method, this parameter proved to be critical. The present method proved to be robust since the adjustments made did not cause changes outside the parameters determined (Table 2) (International Conference on Harmonisation of Technical Requirements for Registration of Pharmaceuticals for Human Use, 2005; Agência Nacional de Vigilância Sanitária, 2019).

Table 2: Concentrations obtained from the analyses were performed by varying the chromatographic parameters by $10 \%$. Statistics performed by ANOVA with Dunnett's Multiple Comparison Test $(p<0,05)$

\begin{tabular}{|c|c|c|c|}
\hline $\begin{array}{l}\text { Chromatographic } \\
\text { conditions }\end{array}$ & $\begin{array}{c}\text { Mean } 5 \mu g \mathrm{~mL}^{-1} \\
\mathrm{n}=3\end{array}$ & $\begin{array}{c}\text { Mean } 15 \mu \mathrm{g} \mathrm{mL}^{-1} \\
\mathrm{n}=3\end{array}$ & $\begin{array}{c}\text { Mean } 25 \mu \mathrm{gL}^{-1} \\
\mathrm{n}=3\end{array}$ \\
\hline $0.9 \mathrm{ml} \mathrm{min}-1$ & $98 \%$ & $100 \%$ & $102 \%$ \\
\hline $1.1 \mathrm{ml} \mathrm{min}-1$ & $99 \%$ & $98 \%$ & $100 \%$ \\
\hline $27^{\circ} \mathrm{C}$ & $103 \%$ & $101 \%$ & $101 \%$ \\
\hline $33^{\circ} \mathrm{C}$ & $98 \%$ & $104 \%$ & $104 \%$ \\
\hline $27 \mathrm{mmol}$ of TEA & $102 \%$ & $100 \%$ & $100 \%$ \\
\hline $33 \mathrm{mmol}$ of TEA & $101 \%$ & $101 \%$ & $101 \%$ \\
\hline
\end{tabular}

\section{CONCLUSION}

The analytical method to determine 4-AD in pharmaceutical formulations, in particular, ophthalmic inserts using HPLC-DAD, proved to be simpler and cheaper than the existing methods, as it does not use the mass spectrometry technique. In addition, the method was demonstrated as accurate, precise, and robust and can be applied in routine analyzes of the described formulation.

\section{ACKNOWLEDGMENS}

The authors would like to thank CAPES, CNPq and FAPEMIG for financial support.

\section{REFERENCES}

Agência Nacional de Vigilância Sanitária - ANVISA. Farmacopeia Brasileira. 6. ed. Brasilia: ANVISA; 2019. Vol. 1.

Alvarez-Lorenzo C, Anguiano-Igea S, Varela-García A, Vivero-Lopez M, Concheiro A. Bioinspiredhydrogels for drug-elutingcontactlenses. Acta Biomater. 2019;84:49-62. http://dx.doi.org/10.1016/j.actbio.2018.11.020. PMid:30448434.

Atsriku C, Watson DG, Tettey JN, Grant MH, Skellern GG. Determination of diminazene aceturate in pharmaceutical formulations by HPLC and identification of related substances by LC/MS.J Pharm 
Biomed Anal. 2002;30(4):979-86. http://dx.doi.org/10.1016/S0731-7085(02)00450-8. PMid:12408888.

Benoist d'Azy C, Pereira B, Chiambaretta F, Dutheil F. Oxidative and anti-oxidative stress markers in chronic glaucoma: a systematic review and meta-analysis. PLoS One. 2016;11(12):e0166915. http://dx.doi.org/10.1371/journal.pone.0166915. PMid:27907028.

Brasil. Agência Nacional de Vigilância Sanitária - ANVISA. Resolução RDC nº 166 de 24 de julho de 2017. Diário Oficial da União [Internet]; Brasília; 25 jul 2017. [cited 2019 Jul 24] Available from: http://portal.anvisa.gov.br/documents/10181/2721567/RDC_166_2017_COMP.pdf/d5fb92b3-6c6b4130-8670-4e3263763401

Calles JA, Bermúdez J, Vallés E, Allemandi D, Palma S. Polymers in ophthalmology. In: Puoci F, editor. Advanced polymers in medicine. USA: Springer International Publishing; 2015. p. 147-176.

Campbell M, Prankerd RJ, Davie AS, Charman WN. Degradation of berenil(diminazene aceturate) in acidic aqueous solution. J Pharm Pharmacol. 2004;56(10):1327-32. http://dx.doi.org/10.1211/0022357044409. PMid:15482649.

Carta F, Osman SM, Vullo D, Gullotto A, Winum JY, AlOthman Z, Masini E, Supuran CT. Poly(amidoamine) Dendrimers with Carbonic Anhydrase Inhibitory Activity and Antiglaucoma Action. J Med Chem. 2015;58(9):4039-45. http://dx.doi.org/10.1021/acs.jmedchem.5b00383. PMid:25849626.

Carvalho IM, Marques CS, Oliveira RS, Coelho PB, Costa PC, Ferreira DC. Sustained drug release by contact lenses for glaucoma treatment-a review. J Control Release. 2015;202:76-82. http://dx.doi.org/10.1016/j.jconrel.2015.01.023. PMid:25617723.

Desai AR, Maulvi FA, Pandya MM, Ranch KM, Vyas BA, Shah SA, Shah DO. Co-delivery of timolol and hyaluronic acid from semi-circular ring-implanted contact lenses for the treatment of glaucoma: in vitro and in vivo evaluation. Biomater Sci. 2018;6(6):1580-91. http://dx.doi.org/10.1039/C8BM00212F. PMid:29708242.

Faraco AA, França JR, Cronemberger S, Alves R, Navarro L, Cesar ALA, Castilho RO, Ferreira AJ, Foureaux G, Silva R, Santos J, Fraga F, Nogueira, J, Castro C, Lacerda I. inventor; Universidade Federal de Minas Gerais (BR/MG); Fundação de Amparo à Pesquisa do Estado de Minas Gerais - FAPEMIG (BR/MG); Universidade Federal de Goiás (BR/GO), assignee. BR 1020180705644 A2. 2020 Apr 22.

Foureaux G, Franca JR, Nogueira JC, Fulgêncio GO, Ribeiro TG, Castilho RO, Yoshida MI, Fuscaldi LL, Fernandes SO, Cardoso VN, Cronemberger S, Faraco AA, Ferreira AJ. Ocular inserts for sustained release of the angiotensin-converting enzyme 2 activator, diminazene aceturate, to treat glaucoma in rats. PLoS One. 2015;10(7):e0133149. http://dx.doi.org/10.1371/journal.pone.0133149. PMid:26204514.

França JR, Batista LD, Ribeiro TG, Fernandes C, Castilho RO, Faraco AA. Development and validation of a high performance liquid chromatographic method for determination of bimatoprost in chitosanbased ocular inserts. Anal Lett. 2015;48(3):531-40. http://dx.doi.org/10.1080/00032719.2014.947533.

Franca JR, Foureaux G, Fuscaldi LL, Ribeiro TG, Rodrigues LB, Bravo R, Castilho RO, Yoshida MI, Cardoso VN, Fernandes SO, Cronemberger S, Ferreira AJ, Faraco AA. Bimatoprost-loaded ocular inserts as sustained release drug delivery systems for glaucoma treatment: in vitro and in vivo evaluation. PLoS One. 2014;9(4):1-11. http://dx.doi.org/10.1371/journal.pone.0095461. PMid:24788066.

Gooch N, Molokhia SA, Condie R, Burr RM, Archer B, Ambati BK, Wirostko B. Ocular drug delivery for glaucoma management. Pharmaceutics. 2012;4(1):197-211. http://dx.doi.org/10.3390/pharmaceutics4010197. PMid:24300188.

Gupta S, Samanta MK, Raichur AM. Dual-drug delivery system based on in situ gel-forming nanosuspension of forskolin to enhance antiglaucoma efficacy. AAPS PharmSciTech. 2010;11(1):322-35. http://dx.doi.org/10.1208/s12249-010-9388-x. PMid:20182824.

International Conference on Harmonisation of Technical Requirements for Registration of Pharmaceuticals for Human Use - ICH. Validation of analytical procedures: text and methodology Q2 (R1). In: International Conference on Harmonization; 2005; Geneva, Switzerland. European Union: ICH; 2005. p. 1-17.

Karki S, Kim H, Na SJ, Shin D, Jo K, Lee J. Thin films as an emerging platform for drug delivery. Asian J Pharm Sci. 2016;11(5):559-74. http://dx.doi.org/10.1016/j.ajps.2016.05.004. 
Maia ALC, Fernandes C, Silva TD, Oliveira CNP, Silveira JN, Ramaldes GA. Development and validation of high performance liquid chromatographic and derivative spectrophotometric methods for determination of gadodiamide in liposomal formulations. Anal Methods. 2015;7(19):8315-25. http://dx.doi.org/10.1039/C5AY01709B.

Mu C, Shi M, Liu P, Chen L, Marriott G. Daylight-mediated, passive, and sustained release of the glaucoma drug Timolol from a contact lens. ACS Cent Sci. 2018;4(12):1677-87. http://dx.doi.org/10.1021/acscentsci.8b00641. PMid:30648151.

Ribeiro FAL, Ferreira MMC, Morano SC, Silva LR, Schneider RP. Planilha de validação: uma nova ferramenta para estimar figuras de mérito na validação de métodos analíticos univariados. Quim Nova. 2008;31(1):164-71. http://dx.doi.org/10.1590/S0100-40422008000100029.

Rodrigues LB, Leite HF, Yoshida MI, Saliba JB, Cunha AS Jr, Faraco AAG. In vitro release and characterization of chitosan films as dexamethasone carrier. Int J Pharm. 2009;368(1-2):1-6. http://dx.doi.org/10.1016/j.ijpharm.2008.09.047. PMid:18955123.

Rodriguez-Aller M, Guinchard S, Guillarme D, Pupier M, Jeannerat D, Rivara-Minten E, Veuthey JL, Gurny R. New prostaglandin analog formulation for glaucoma treatment containing cyclodextrins for improved stability, solubility and ocular tolerance. Eur J Pharm Biopharm. 2015; 95(Pt B):203-14. http://dx.doi.org/10.1016/j.ejpb.2015.04.032

Sharif NA. Ocular hypertension and glaucoma: a review and current perspectives. Int Jour Ophth Vis Sci. 2017;2(2):22-36. http://dx.doi.org/10.11648/j.ijovs.20170202.11.

Silva JA, Guimarães GP, Patriota YBG, Silva NES, Sousa CEM, Mendonça FJB Jr, Santana DP, Damasceno BPGL. Desenvolvimento e validação de metodologias analíticas para quantificação de um derivado tiofênico em sistemas microemulsionados. Rev Cienc Farm Basica Apl. 2014;35(4):643-9.

Snyder LR, Kirkland J, Glajch JL. Practical HPLC method development. 2nd ed. New York: WileyBlackwell; 1997. http://dx.doi.org/10.1002/9781118592014.

Souza JF, Maia KN, Patrício PSO, Fernandes-Cunha GM, Silva MG, Jensen CEM, Silva GR. Ocular inserts based on chitosan and brimonidine tartrate: development, characterization and biocompatibility. J Drug Deliv Sci Technol. 2016;32:21-30. http://dx.doi.org/10.1016/j.jddst.2016.01.008.

Wang BB, Lin MM, Nguyen T, Turalba AV. Patient attitudes toward novel glaucoma drug delivery approaches. Digit J Ophthalmol. 2018;24(2):16-23. http://dx.doi.org/10.5693/djo.01.2018.07.001. PMid:30800009.

Wang J, Zhao F, Liu R, Chen J, Zhang Q, Lao R, Wang Z, Jin X, Liu C. Novel cationic lipid nanoparticles as an ophthalmic delivery system for multicomponent drugs: development, characterization, in vitro permeation, in vivo pharmacokinetic, and molecular dynamics studies. Int J Nanomedicine. 2017;12:8115-27. http://dx.doi.org/10.2147/JJN.S139436. PMid:29158673.

Wang Y, Rajala A, Rajala RV. Lipid nanoparticles for ocular gene delivery. J Funct Biomater. 2015;6(2):379-94. http://dx.doi.org/10.3390/jfb6020379. PMid:26062170.

Yadav KS, Rajpurohit R, Sharma S. Glaucoma: current treatment and impact of advanced drug delivery systems. Life Sci. 2019;221:362-76. http://dx.doi.org/10.1016/j.Ifs.2019.02.029. PMid:30797820.

Zhu Q, Cheng H, Huo Y, Mao S. Sustained ophthalmic delivery of highly soluble drug using pH-triggered inner layer-embedded contact lens. Int J Pharm. 2018;544(1):100-11. http://dx.doi.org/10.1016/j.ijpharm.2018.04.004. PMid:29627356.

\section{Author contributions}

Aina Liz Alves Cesar: conceptualization, writing, data curation, methodology, formal analysis; Larissa Caldeira Navarro: technical support, methodology, formal analysis; Alaíde de Matos Silva: technical support, writing, data curation; Rachel Oliveira Castilho: conceptualization, revision, formal analysis; Gisele Assis Castro Goulart: conceptualization, revision, formal analysis; Giselle Foureaux Heida: conceptualization, funding acquisition, supervision; Anderson José Ferreira: conceptualization, funding acquisition, supervision; Sebastião Cronemberger: conceptualization, funding acquisition, supervision; André Augusto Gomes Faraco: conceptualization, funding acquisition, supervision, formal analysis. 